\title{
The Internationalization of Higher Education in the West Indies
}

\author{
Patrick Coggins \\ Department of Education, Stetson University, USA \\ Email: pcoggins@stetson.edu
}

\begin{abstract}
This chapter explores the coalescence of the modern tertiary education system of the West Indies, and the historical and geopolitical factors that influenced the movement to establish higher education institutions in the Caribbean region. Four recommendations are offered to strengthen the enrollment of Caribbean students while sustaining a competitive higher education system.
\end{abstract}

Keywords: Tertiary Education, Caribbean Higher Education, British Colonialism, University College of the West Indies, Federation of the West Indies, Internationalization

\section{Introduction}

The purpose of this chapter is to examine the history, contributions and current status of Higher Education in the West Indies, also known as the Caribbean Region. The focus of this chapter is limited to the British West Indies where there was more documented evidence of 
attempts to successfully implement an elementary, secondary and tertiary educational system which included colleges and universities in higher education. The colonialization process saw the initial institutions limiting their admission to children of the colonial overseers while the admission of local indigenous children were few in number. The result of colonialization meant that the West Indies became an important economic fixture to global empires. Then came independence movements in the West Indies which successfully earned the right to self-governance, independence and the creation of new nations in such places as Barbados, Trinidad, Guyana, Jamaica, the Virgin Islands, Belize (formerly British Honduras), Grenada, and the Cayman Islands, to mention a few. The challenge for the West Indies nations has been to encourage financial and other support from the former colonial powers, but, at the same time to work hard to establish a higher education system that is international in its curriculum and an attractive alternative for students from the United States of America, Canada, Europe, Latin America, and throughout the Caribbean. These nations also strive to support each other's economic welfare in a global context as the region experiences renewed international focus and as they become globalized entities through an abundant tourism industry and real estate market attracting the economic forces of the US and Canada. Thus, this chapter will explore the historical development, the shifts in control, and the contemporary status of access and control of higher education in the Caribbean, particularly the former British West Indies.

\section{Spanish Colonial Education}

Since the $15^{\text {th }}$ Century, the European powers governed colonial holdings in the Americas and the West Indies. These powers included the British, the French, the Dutch, and Spanish. The idea of higher education was debated heatedly. It was a topic of great political debate especially since during the colonial period education policy was dictated by the colonial power ruling the home country with little say from the people living in these colonies. Governors abided by the rules of their home governments, and limited active attempts were made at creating a higher education system, or more basically, a formal elementary and secondary education system in the colonies under the control of the colonial government. However, after the foundation of the first European colonies, the colonial powers began exploring education options for their settlers already in the New World (Roberts, Rodriguez, $\&$ Herbst, 1996). Since the colonial powers saw the need to create both a basic educational as 
well as a tertiary educational system, the objective to develop a core group of well-educated colonists overseas was to sustain local management of the colonies .

In the early 1500 s, however, European countries began shipping slaves from West Africa to help settle and work plantations in their Caribbean colonies. The original African slaves were brought to help the Spanish procure precious sugar for the rum supplies since the natives they had enslaved were dying off rapidly from disease and exhaustive work (Caban, Cruz, Carrasco, \& Garcia, 1994). To counter this dying group, the Spanish began bringing over African slaves to the New World. This process of slave trade was proposed in 1503 by Bartolome de las Casas who recommended Africans be brought to the Americas to replace their dying native populations (Roberts et al., 1996). These enslaved African populations soon began to grow rapidly, and the African diaspora began to spread throughout the Caribbean in places such as Haiti, the Dominican Republic, Puerto Rico, the Virgin Islands, Jamaica, and the Cayman Islands. With this in mind, universities and education in the New World became a necessity in order to create a stable educated middle class who were capable of managing the affairs of the various colonial countries in the West Indies.

One of the first universities in the New World appeared in 1538 when Spain ordered the creation of the Universidad de San Domingo, a private university specializing in law and theological education in San Domingo, Dominican Republic (Roberts et al., 1996). It had a population of over 150 students seeking studies in Spanish law and Catholic missionary work. However, this university, like most others to follow it, would be open only to Europeans with no attempts to educate and include students from the native local populations and or the enslaved Africans.

The Spanish were the first European powers to begin opening universities in their colonies throughout the 1500s. A distinct difference should be noted between the European nations at the time competing for colonial control in the region. By the late $16^{\text {th }}$ Century, the Spanish gained immense wealth through mining minerals, while sugar and slave trading merely added more to the bustling Spanish colonial economy. Spanish colonial society was also distinctly European. Many colonists lived in large urban cities such as Havana or San Juan with European architecture and a very heavy Spanish influence. One might even mistake the location in these Caribbean cities for monuments in Spain itself (Roberts et al., 1996).

The British and the Dutch had vastly different systems. Whereas the Spanish were churning out wealth where they could, mostly through mining gold and silver in their colonies in South 
America and Mexico, the British and the Dutch stuck mostly to plantation economies to bring wealth to the homeland throughout the early to mid-1600s. The British, however, had the Thirteen American Colonies to the North, as well as Canada, giving them equal resources and opportunities for trade and wealth as the Spanish (Williams, 1964).

But the Spanish and the British stuck to restoring academia in places where it better suited them: in mostly white-majority settlements like the North and South American colonies. These included the Spanish colonies of New Granada, Peru, and Colombia.

\section{Early Colonial Attempts for a University System}

As the centuries passed, more and more universities founded by Europeans for Europeans sprung up across the colonies such as the University of Lima in Peru in 1551, Santo Tomas in Bogota in 1580, and Quito in 1586. As time went on, the European population grew very little in places such as the West Indies where slave populations exploded. Even with a booming slave population, thousands of slaves were brought over every year from West Africa. The educational system continued to support Europeans above all. The only education slaves were given were from their masters or from the missionary services that taught them biblical and theological information, rather than civic law and literature (Cobley, 2000).

Much of the education the Europeans brought to the New World tended to be religious in nature and definition. This remains true with the first higher education institution in the British West Indies which was known as Codrington College. The college was named after Christopher Codrington III (1668-1710), the main benefactor of the college. He was born on a wealthy plantation in St. Michaels and rose up through colonial society. As a young man, he joined the British Army and served as an officer before returning to Barbados to succeed his father as Governor General of the Leeward Islands. Later on, he gave up the position of governor and retired, giving most of his wealth to the college before his death on April 7, 1710. As it was Codrington's desire to Christianize the slaves in Barbados, the college followed its benefactor's wishes and began opening its classes for theological courses and education in missionary studies (Cobley, 2000) .

Codrington College, established in Barbados in 1743, was primarily opened for the training and educating of Anglican priests. The major concern for Europeans up until the mid-1700s was retaining religious authority over native and slave populations. Missionaries became the most educated individuals in the Caribbean, while native Indians and Africans received 
limited formal elementary education beyond repeating verses in the Bible (Cobley, 2000). As the population grew and more European settlers arrived into Barbados, the college sought to provide general education courses to White middle-class colonists. It also provided courses in philosophy and mathematics, though by 1759 the college was geared largely toward the sons of the White plantation-owning gentry whose sons might have otherwise left for England for their educations. The college continued serving the gentry until 1830, when the Anglican Church ordered to have it converted to its first purely theological college predating Chichester College in England (1839), and Wells College (1840) (Cobley, 2000).

Codrington College remained a primarily White institution for most of the $18^{\text {th }}$ Century, however, as diverse populations continued to grow, colonists in the West Indies and the British Caribbean began turning their attention away from basic agricultural needs and religious welfare and began seeking a cadre of people equipped through training in maintaining a civil society (Williams, 1964). The Spanish universities in Latin America and the Caribbean were superior in training lawyers, doctors, and other civil servants which enabled the colonists to maintain a stable colonial society. The British sought to create a civil colonial society in the West Indies throughout the late $18^{\text {th }}$ Century. This source of higher education was based primarily on the European system of colleges and universities (Williams, 1964).

In the British North American Colonies, higher education was vastly much more developed and advanced than the simple missionary-religious education of the Caribbean region. Howe (2000) suggests that this is due to the fact that the American colonies had greater interests, greater resources, and a much larger population seeking higher education opportunities. By 1750, the American colonies had nine universities, a majority in North America. These included Harvard College, in Massachusetts, King's College in New York City, the College of William and Mary in Virginia, and Queen's College in Rutgers, New Jersey. It is believed that the neglect and underdevelopment of universities in the Southern colonies, including the West Indies, was due in part to a much more agrarian society mixed with a large slave population (Howe, 2000). The colonial elites felt it unnecessary to focus higher education on skilled careers such as medicine and law in areas that were in higher demand for farmers and planters. Another factor to consider is the few university alumni that existed within the Caribbean colonies compared to the Americas. Howe (2000) suggests that by 1750 there were fewer than 150 total graduates of European universities settled in the West Indies, compared to 2,000 or more in the New York Colony alone. The vast degrees of separation 
between them would make founding a colonial university much harder in the West Indies. Thus, the need for a higher education system in the Caribbean became a pragmatic decision for everyone during the colonial period in the West Indies.

\section{Laying the Foundations for Higher Education in the West Indies}

In 1808, the Universal Declaration of Slavery ended the formal slave trade between Africa and the Atlantic colonies (Banks, 2009). By 1830, the political idea of slavery had begun to change from an economic to a moral issue. Finally, in 1834, British Parliament voted to abolish slavery everywhere it had existed throughout the British Empire (Cobley, 2000). This came some thirty years before the United States of America would pass the $13^{\text {th }}$ Amendment to the U.S. Constitution in 1865. With the legal abolition of slavery, massive slave populations in the Caribbean found their freedom and quickly became the majority citizenry in the colonies.

Following the emancipation of slavery in the United States America in 1865, the British government began looking at what they could do to maintain order and establish a civil colonial society that would help ensure stability among these populations. Despite the fierce backlash from European settlers and former slave owners, there were repeated attempts to form a university in the West Indies for the purpose of training and educating these freed populations for the assumption of active roles in civil societies throughout the West Indies (Morrison, 2014). Though the planter elite still managed to keep these fledgling freed slaves down for years, the plan was set in motion to initiate a system of higher education that was tailored to the freed slaves and would create an educated class among both the European and African and Native Indian populations.

\section{Earliest Development of Higher Education in the West Indies}

One of the earliest attempts for a West Indian higher education institution came from English Bishop John Berkeley. In 1843, Berkeley called for Bermuda to be transformed, and in a way internationalized the school, to house a major university for both the Caribbean and American students. Although this never happened immediately, it nonetheless helped fuel the support for a "Negro Education Grant" passed by British Parliament to help support missionary societies in educating freed slaves (Cobley, 2000). 
In 1843, Christian missionary societies provided the backbone of education to colonial civil society in the West Indies for a time. Due to the West Indies being less developed than their North and South American counterparts, the West Indies were forced to rely on Christian missionaries to bring medicine, civic, and vocational education to the colonies through educated Europeans taught in European vocational universities. These missionary societies were often structured around a central parish established on the colony in hopes of growing through converting masses of locals to the dominant religious perspective.

With the debate on how to handle higher education still raging, the job fell on the Christian missionary societies in the West Indies to support the formative educational system until the home government could find a way to settle the issue by making higher education a priority. Thus, in 1843, the Baptist Missionary Society pooled funds to help found Calabar College in Jamaica to train ministers from throughout the world including the Caribbean and South America (Howe, 2000). In 1844, Calabar College was transformed to help support nondenominational education and the curriculum was expanded to include teaching a range of secular subjects in the arts and sciences. Calls from the British government to establish a strictly nondenominational, government-funded university were addressed with great excitement and determination to develop a higher education system for all residents alike (Howe, 2000).

In London in 1844, colonial authorities met to discuss how to properly handle the education issue in the West Indies. It became clear the colonial government wanted to institute a system to control the newly freed black populations, while the national government wanted to give opportunities to these populations beyond unskilled agricultural labor. Thus, in 1868, the government dispatched Patrick Joseph Keenan, Chief of the Inspection Board for Education in Ireland for the British government, to the West Indies to assess the state of education in Trinidad (Cobley, 2000). When he returned in 1869, he reported to the government that the lack of educational opportunities in the British colonies concerned him and that the current method of providing higher education to only the colonists was inefficient and not costeffective. For years, colonists and native citizens had to send their children halfway around the world to gain a college education, spending fortunes and years separated from their children in order for them to gain an education in Europe.

The prospect of living at home while being educated in a higher education institution in one's own country was certainly a desire of everyone who lived in the Caribbean during this postcolonial period that freed Africans in the colonies. 


\section{The Keenan Report and its Impact on Higher Education}

Patrick Keenan had been the Commissioner of Education for Ireland at a crucial period in the history of his country. During the Potato Famine of 1850, many of the people who spoke Gaelic Irish died out as a result of the famine. When the British entered the nation's political sphere to alleviate the calamity, the Gaelic died off and English became the primary language of the Irish (Gordan, 1962). Keenan was responsible for ensuring that the education system in Ireland was transformed to meet the new focus. This new focus was due to the British imposing secular schooling on the Irish population, something that many Catholics, who sent their children to Catholic schools, and nationalists who did not want to see their country turn into replicas of British subjects. Rather, Ireland transformed economically and the Anglicized secular education system reinvigorated the middle class. Ireland was back to prosperity by 1865 and so was a new sense of urgency for the development of a substantive education system that benefited many.

The view of the Ministry of Education was that Trinidad and Ireland were in the same position. Trinidad and Ireland had a rising middle class hampered only by their limited educational opportunities. When Keenan arrived in Trinidad, a colony in the West Indies, he observed the primarily religious and vocational education the local colonists were emphasizing its educational system (Cobley, 2000; Gordan, 1962).

As such, Keenan continued his stay in Trinidad, and his report back to London was filled with a litany of shocking reports on the limitations of the educational system in the West Indian colony. During his stay, Keenan had become sensitive to the multiracial fabric of the West Indies. This racial diversity influenced Keenan, however, to push for separate schooling, similar to the segregated education of White and Black youths in the American South during the $20^{\text {th }}$ Century. Keenan detailed in his report that he felt Indian children and African children were both of high intellectual caliber, but together, the Black and White populations would be unable to compete with their Indian counterparts. Thus, Keenan pushed for segregated public schooling for the middle and lower-class people divided by race, and proposed estate-sponsored schools, funded by the money of key planters on the islands, for the children of the upper echelon of colonial society.

Ultimately, Patrick Keenan wanted to save the people, and the government, money by localizing colonial higher education (Cobley, 2000; Gordan, 1962). His reports were greatly appreciated on behalf of the Ministry of Education, who continued to fund his commission 
until he returned to England in 1870. The Keenan Report elaborated on the need for the colonies to have a university in the West Indies to properly train and build up colonial society through educational opportunities. The report criticized the local elites' control over education and the opportunities for the freed people to seek education within their homeland. Thus, he made the first request for a European-style university to be built in the West Indies. However, the Colonial Ministry failed to acquiesce to the Keenan Report and no funds were provided for the next decade. For much of the next two decades, the 1880s and 1890s, the responsibility for higher education would rest in the territorial government to create such an institution.

The Keenan Report greatly impacted the traditional view of colonial education. Though the Ministry of Education in London failed to implement Keenan's recommendations, efforts began within the colonies themselves to begin funding schools to increase their educational opportunities for all peoples in the colonial society (Gordan, 1962). Although London preferred to have higher-level students attend educations in Oxford and Cambridge, the colonists continued to look for options to begin the foundation of a homeland education system. Keenan continued to advocate that opening a university in the West Indies region would save money for both the colonies and the British government in the long run, but London ignored his requests. The colonies, however, embraced them and pushed for the implementation of a University system in the West Indies.

\section{Initial Failures in Implementing the Higher Education System in Jamaica}

In 1873, the colonial government of Jamaica attempted to launch a public university. However, due to lack of funds and opposition within the colonial government, the opposition movement forced the governor of Jamaica to abandon the project. Efforts in 1876 were also made in Barbados where Anglican Bishop Mitchinson tried to convince the colonial legislature to pool funds together for a scholarship to allow a couple of the highest achieving students in Barbados to attend the universities of Oxford or Cambridge in order to achieve a higher education (Howe, 2000).

Similar scholarships were granted to the governments of Jamaica and Trinidad. For a time, these scholarships became highly sought after by many students in the West Indies, but time proved them to be inefficient and costly. Another effect this had was that it allowed the 
European elite to exclusively take advantage of these scholarships to send their children off for free education in Europe, while West Indian students were forced to undergo stricter testing and unfair academic standards which combined to limit access to higher education opportunities.

Attempts once again were made in 1889 and 1898 to fund a university for the territories in the West Indies. Although neither proved successful, the colonial governments had sought to allow students who could not access scholarships to Oxford or Cambridge to take secularbased classes at Codrington College, these classes being sponsored by the University of Durham in North East England (Cobley, 2000). In 1876, the colonial governments of the West Indies sought instead to develop an internal/local education system in the West Indies rather than shipping their students off to study at external campuses in England and France. When the link between Codrington in Barbados and Durham in England became wellpublicized throughout the academic world in 1878, it became clear Codrington was becoming the best option for indigent West Indian students as they could achieve university-level degrees without having to travel across the Atlantic to Europe to do so.

It took several decades between 1880 and 1900, but, the idea for a regional university in the British Caribbean would lose popularity for a time as economic crises began to take hold throughout the territories. The decline of sugar output in these territories began a period of economic and social stagnation. During this interim, the only publically supported higher education institution throughout this region was a public teacher training college in Jamaica with just a few hundred students in the late 1880s (Morrison, 2014). Not until after WWI would the idea once again be revived with new energy to develop a university system geared to the children of both colonial parents and indigenous African and other non-white ethnic populations.

\section{Impact of WWI on Higher Education in the Caribbean: 1914-1929}

In 1914, the First World War produced many devastating results for the British Empire. Though Britain maintained superior political and military might to that of her enemies, the war distracted the nation from maintaining its colonial affairs in the Western Hemisphere as well as deal with the threat of the Central Powers in Europe and in its colonial holdings in Africa and the Middle East. Entire government budgets were stripped down to fund the war 
effort, and millions of Britons and colonists from across the world enlisted to fight for the Empire during WWI (Downes, 2013).

Though Britain arose victorious alongside France and the United States, the WWI showed the British government just how fragile the Empire really was. WWI brought to an end the Age of Colonialism in which European powers, as well as the United States, were taking over less developed regions and absorbing them into their empire, extrapolating resources for trade. Nations like France and Britain had given everything to fight the war only to find that their empires were now on the edge of collapsing politically and economically (Downes, 2013).

Beginning in 1919, the British government reexamined its policies in its colonies, especially the West Indies, to find solutions to make their policies toward their territories more consistent and comprehensive with regards to self-government (Downes, 2013; Williams, 1964). The general view was that Britain would do whatever it took to keep the Empire alive politically and economically. This meant they needed to legitimize and maintain political control over their colonies, but to do so they needed their colonies to be stabilized and happy to live under British rule. Their first step was to conduct an overhaul of civil services in the colonies and specifically education for the masses of people living in the colonies. This included a policy that developed and sustained an elementary, secondary, and tertiary educational system in the former colonies.

\section{The Acquiescence to Establish a Second College}

The British government, finally acquiescing to the demands of their citizens in the West Indies, agreed to establish the Imperial College of Tropical Agriculture (ICTA) in Trinidad in 1921 (Cobley, 2000). This became the second institution of higher education in the region after Codrington College. After 1921, attitudes toward a university for the region became much more open. By 1923, there was a shift in attitudes by the British government to allocate funding for such a venture. The British Advisory Committee on Education in the Colonies, created by the Secretary of State for the Colonies, was formed in response to American interest in opening up a similar university in West and South Africa (Gift \& Bell-Hutchinson, 2007). Although their focus was originally on elementary to high school education, considerations were raised about opening a multipurpose university in the region in order to address the tertiary educational needs of all citizens in the Caribbean region. 
By 1926, the internationalization of higher education again took root. The British Colonial Office was looking to open similar universities throughout the British Empire. They did this for multiple reasons. First, they wished to offer higher education opportunities to help train indigenous citizens on how to deal with local issues as the war had reduced the number of experienced colonial administrators. These indigenous citizens would go on to serve as lawyers, doctors, and civil servants trained in the colonies within a British system. Secondly, government authorities were growing concerned about the rising political consciousness of the colonial indigenous populations as they sought further autonomy and self-reliance following the World War I. Another great fear was that shipping students from the territories such as West Africa and the Caribbean to places like Oxford and Cambridge would only fuel their nationalist sentiments (Downes, 2013). This would lead to more trouble as they had the possibility of returning home as well educated revolutionaries educated by the British themselves. Thirdly, the British government feared bringing in foreign colonials into the motherland as racial tensions increased in the British Isles and possessions including the British West Indies (Downes, 2013).

Throughout WWI, the British were quick to accept the aid of Africans, Indians, and West Indians to fight for them. However, these units were split into separate fighting units led by British commanders and there were no racial/ethnic intermixing of these units. After the war, tensions which were thought subsided, quickly grew once more. With the war over, the Great Depression loomed over the Empire. The British soon began restricting brown and black people from acquiring jobs in a shrinking job market and banned them from civil servant positions in Great Britain (Ajayi, Goma, \& Johnson, 1996). Race riots ensued in 1919 and 1920, and attempts were made to repatriate the brown and black colonials residing in Britain and restrict the entry of African and Indian colonials from entering Britain (Cobley, 2000). Britain continued to fear the worst, as they were scared to see what would happen in the colonies when news got back of Indian and African citizens being assaulted in street riots and deported from the nation they had fought for. Students especially, began expressing their concerns toward the situation and many argued for the need for more education and selfdetermination in their homelands. 


\section{Racial Discrimination against Blacks and Colored Colonial Citizens}

By 1921, students began writing letters of complaint to the British Colonial Office and the Ministry of Education to protest treatment they received. Many of these students were upcoming doctors and lawyers completing their training and readying to return home. Students formed interest groups such as the Coloured People's League and the West African Students Union to ensure their voices were heard. Their letters spoke to the Colonial Office, and told them that the negative racial treatment they received in Britain would have farreaching effects for the Empire (Ajayi, Goma, \& Johnson, 1996). Thus, Parliament passed legislation to protect the rights of colonial students studying in Britain, but by then, the damage had been done. The British Colonial Office expressed that they had set the hopes of these colonials too high and there was nothing more they could do. It would take half a decade for the British to realize their mistake. It only fueled the nationalist sentiments of those students who would return to lead independence movements in the Caribbean, India, and Africa over the next two decades. The main focus of these movements were 1) Internal self-governance, 2) Economic and political control of economic resources, and 3) A dynamic educational system that includes elementary, secondary, and tertiary education as a basic right for all citizens. The impetus for the development of a series of higher education institutions in the West Indies became the focal point of British policy.

\section{The Real Reason Universities/Higher Education Developed in the West Indies}

Interestingly enough, this unfair treatment also spurred the British government to consider finally giving funds to establish a university college in the West Indies. This was brought about by the results of two reports. The first was the Mayhew-Marriott Report in 1932 which spoke about the systems of elementary, secondary, and vocational education in the Caribbean. This report noted that a great deal of cooperation existed between the countries in the West Indies. Noting this exchange between the colonies, the Colonial Office agreed to oversee the development of a university for the region funded and supported by local provisions (Braithwaite, 1965). It was clear that this report stated that the future of the region's stability within the British Empire depended upon the development of a tertiary university system of education. Although this may have been done to lessen the number of foreign students arriving in Britain and attending British universities, this establishment of an alternative 
higher education system in the region where West Indian students lived was well intentioned and proved to be a positive and rational decision in addressing tertiary education for West Indian student populations.

Although the British government wished for the colonies to pay for their education themselves, this attitude changed in the latter half of the 1930s as race riots and anti-colonial sentiments swept the British Empire. It became clear colonial citizens could not afford an Oxford/Cambridge education on their own without government assistance. Nowhere was this more apparent than in the West Indies where race riots broke out through the islands as the black working class protested wages. A Royal Commission under Lord Moyne was sent to the West Indies in 1938 to find the root cause of these riots (UWI, 2014). His report back to the British government suggested sweeping political and administrative reforms to the colonial authority, as well as improved educational systems and the establishment of a Colonial Welfare and Development Fund, an international bank of sorts for the British colonies. The British government saw overhauling colonial policy as an urgent matter if the Empire wanted to survive and this overall must include a sound higher education system for the indigenous populations in the countries in the West Indies.

In response to this report, the British government began laying the groundwork for a University College of the West Indies (UWI, 2014). However in 1938, it was still under the assumption that a university in the region would still be controlled for the White colonial elites of the islands. This all changed with the outbreak of World War II and the revolutionary desire of the native Blacks and Brown people to ensure that education was a fundamental right for all not just a few White elites. This innate desire to receive a good quality higher education became the battle cry for many native populations living under British colonial rule (Downes, 2013).

\section{The Second World War and the Founding of UCWI: 1939-1948}

The Second World War changed the world irreversibly, in both good and bad ways. It also brought the world, and the British Empire, into the rapidity of modernity. When the outbreak of WWII ravaged Europe, Great Britain found itself as the underdog against the mighty war machine of Germany in Western Europe, and the overwhelmingly superior numbers of the Japanese Empire in the Pacific Theatre. 
In Europe, Britain was isolated and fighting a defensive air war against waves of German bomber squadrons. The Germany military had sealed off Europe from the sea, preventing any major actions by the British on land until the United States entered the war in 1942 and began sending its troops overseas and supplying and leading the Allied war effort.

In the Pacific however, the British were experiencing large numbers of casualties. Their troops were scattered trying to defend far-flung colonies, and with no way to send reinforcements en masse outside of Britain, they were forced to turn toward their colonies in the New World for help (Downes, 2013).

Oddly enough, it was WWII that was the launching pad not just for the University of the West Indies, but also movements propelled by the feeling of self-government and independence as well. A regional university for not just White elites, but local West Indians as well, would become a focal avenue for independence (UWI, 2014).

As the war dragged on, the British continually requested assistance from their West Indian colonies. But they were made to pay a price for this help. For the furthered assistance of the colonies, the West Indies demanded increased self-rule and devolution of government in the Caribbean - meaning they had a greater say in their own affairs free of the constraints of British rule. The British were forced to concede to many rising nationalist demands in order to keep the colonies within the Empire long enough for them to survive the war (Williams, 1964). One of them was for a University in the West Indies opened not just for European elites but for all native people. In order to prevent the colonies from falling out of their hands and causing mass protests and riots, the British agreed to many demands in order to prevent nationalist leaders from leading rallies which they feared would lead to uprisings and weakening of Britain's influence in the colonies.

As the war progressed, the West Indies citizens experienced increased self-determination in their desire to their rule their own destiny. Beginning in 1943, the Asquith Commission under Justice Sir Cyril Asquith began developing a method for a series of universities in the Caribbean, however colonial officials as well as members of the Ministry of Education felt this was too excessive, and that it was far more fiscally responsible to invest in a single university for the region open to all students (Cobley, 2000). The commission consisted of many members of the Oxford faculty wishing to expand further educational opportunities in the Caribbean. 
Over time however, the efforts of the British changed from placating the colonies to soon rewarding them for the merit of their actions. West Indians became productive and efficient contributors to the war effort and the region supported the cause of the Empire in fighting the Japanese and the Germans. Supplies of men and resources poured in from the colonies in order to help maintain Britain throughout the conflict. The various ports throughout the West Indies supported British and American naval vessels by refueling and repairing them during the war. Nearly $50 \%$ of the shipping to Europe and Africa during the war came through the Gulf of Mexico, and the West Indies allowed the US Navy to use their bases and refueling stations to launch these shipping initiatives (Cobley, 2000).

\section{An American Takeover of Caribbean Affairs}

During the war, however, the United States of America assumed the responsibility of the Caribbean region's defense from Britain. This meant that the British could focus their naval assets on Europe as part of the Lend-Lease Program. Many in the Caribbean feared the British were abandoning their promises to increase civil service and education in the region. But because of the commitment of the West Indians to the war efforts, the British continued to provide funding to their educational initiatives while slowly allowing internal selfgovernance of political and educational affairs of the colonies.

During World War II, the West Indies themselves became a location for refugees from the war in Europe to regroup. Thousands of British refugees had fled to the West Indies during the heavy bombings and the fear of a German invasion of London, England. The future location of the University of the West Indies' main campus was the site of Gibraltar Camp in Jamaica, a refugee haven run by the British military to give temporary settlement and aid to the refugees (UWI, 2014). The southeastern part of Mona Island, Jamaica became the home for such a camp. Many of these refugees came from the island of Gibraltar before it was attacked by Axis forces.

By 1945, the Gibraltar camp was closed and the facility was taken over by military authorities. The British placed a Royal Air Force Transit Camp in the location of the refugee haven and the Jamaican colonial authorities were granted access to use the facility as a base for a battalion of troops from the Jamaican Home Guard, the Jamaican colony's military defense force. This was evidence that symbolized a transfer of power of sorts as the Royal military was now more willing to work alongside their colonial counterparts (UWI, 2014). 
As the war came to an end however, focus shifted from defense to modernizing the public services of the colony. In 1945, the Ministry of Education dispatched the Irvine Commission to the West Indies to seek out interest in a public university, as part of the Asquith Commission. They saw an opportunity to use the island of Mona in Jamaica as a suitable candidate location for such a university endeavor (UWI, 2014). The Irvine Commission was quick to want to lay the foundation for a university system. The growing demands of the colonies for the university were increasing especially after the war had come to a conclusion (Williams, 1964).

Following the war, the nearly bankrupt and exhausted British government began turning over numerous responsibilities for their colonies over to the indigenous peoples of the colonies. Beginning in 1946, the British government officially recognized the need for a regional university. The Gibraltar Camp was transferred from military control after the war to the Public Works Department where it was to be vetted as a suitable location for such a campus. Beginning in early 1947, the Public Works Department and the Ministry of Education began swift work to reconfigure buildings and begin making up blueprints for the university (UWI, 2014).

Finally, in December 1947, the Gibraltar camp was reconstructed to fit a university campus and the University College of the West Indies (UCWI) was formed. It welcomed its first students that month. The first class consisted of 23 men and 10 women, all of whom were welcomed in an official ceremony in 1948 (UWI, 2014).

\section{Creation of the Federation of the West Indies: 1949-1964}

The UCWI had its hands full in the first years following its inception. As the student body grew to nearly two hundred, the British were busy trying to find qualified educators to assist in the academic development of the university. Although the university was meant to assist the West Indian locals in honing their skills and seeking an education beyond the agrarian curriculum, the university served two dual paradoxical purposes (Mordecai, 1968).

First, to the colonial governments of the West Indies, the university was a place where West Indians could study in a local and communal environment at an affordable cost without having to spend a fortune getting a bloated European, Oxford or Cambridge education. And secondly, it was a place where local citizens could feel welcomed and accepted alongside Whites and colonial elites, away from the Eurocentric mentality felt in Britain and Europe. 
Nationalism was a key proponent for pushing the university to become more reliant on colonial support, as nationalists within the colonial governments felt that UCWI would promote and spearhead a single West Indian identity separate from that of the identity the British had given them (British Caribbean Federation Act, 1956).

The British government as well had their own agenda for UCWI that coincidentally was similar to the ideas of the nationalists. The British Colonial Office hoped UCWI would help bring together the various national identities and sparsely separated islands into one cogent political unit, which would be easier to manage (UWI, 2014). By the 1950s, the British Empire was beginning to feel the strain of maintaining a global empire. Two factors had begun to lead to this perspective of diminishing control over the colonies.

Firstly, the British Empire found it too costly to maintain so many colonies with rising populations and demands for improved infrastructure. This meant the British would be spending billions of pounds on a global scale restructuring the colonies while Britain herself was recovering in the wake of a global war. Secondly, rising nationalist sentiments, brought about by the globalized aspect of the Second World War, threatened Britain's control of her colonies. Self-rule and semi-independence helped fuel these sentiments in some areas such as India and West Africa (British Caribbean Federation Act, 1956).

By the early 1950s, the British were finding more cost-efficient and less-expensive ways to govern these colonies. This came during a time where Britain was also allocating billions of pounds in defense spending as the Cold War began to heat up. Interventions in Greece in 1948 and Egypt in the 1950s were costly military endeavors.

To counter this, Britain left more of the infrastructural funding and governing to their colonies. With this, many colonies were having financial institutions trying to fund numerous civil departments and programs they hadn't had before. To solve this issue, both nationalists and the British government advocated for the West Indies to federate and pool its resources to sustain the island's own higher education system (Mordecai 1968, p. 122).

In 1958, UCWI increased its enrollment from 30 to nearly 600 students. Many of these students were coming in on government scholarships from the British government and the colonial governments of their home islands. Things were becoming costly as attendance grew. As the cost of tuition grew, so too did nationalist sentiments toward a unified West Indies tertiary system of education (UWI, 2014). 
So in 1958, the British government and the colonial officials of the West Indies announced that the island governments of the region would unite under a single flag, with power divided in a federal structure amongst the islands. This move would both unify the West Indian people under a single national identity while giving the British control over the colonies delegated through the colonial federal government without costly micromanaging (Mordecai, 1968). Table 1 shows the population of the West Indies in 1962 was growing rapidly and total over 3.6 million people who were in the need of education and training in a variety of fields of study.

Table 1 Populations of the States of the West Indies Federation, 1962

\begin{tabular}{cccc}
\hline Province & $\underline{\text { Capital }}$ & $\underline{\text { Population }}$ & Area $\left(\mathrm{km}^{2}\right)$ \\
Antigua and Barbuda & St. Johns & 57,000 & 440 \\
Barbados & Bridgetown & 234,000 & 431 \\
Cayman Islands & George Town & 9,000 & 264 \\
Dominica & Roseau & 61,000 & 750 \\
Grenada & St. George's & 91,000 & 344 \\
Jamaica & Kingston & $1,660,000$ & 10,991 \\
Montserrat & Plymouth & 13,000 & 102 \\
Saint Christopher-Nevis-Anguilla & Basseterre & 55,600 & 351 \\
Saint Lucia & Castries & 95,000 & 616 \\
Saint Vincent and the Grenadines & Kingstown & 83,000 & 389 \\
Trinidad and Tobago & Port-of-Spain & 900,000 & 5,131 \\
Turks and Caicos & Cockburn Town & 6,000 & 430 \\
Federation of the West Indies & Chaguaramas & $3,264,600$ & 20,239 \\
\hline
\end{tabular}

The Federation of the West Indies at its creation had a population of over 4 million, with twelve member states. The capital of the Federation was located in Chaguaramas (Williams, 1964). The formation of the Federation served multiple purposes: to create a single West Indian national identity, unify the economies of the islands to provide increased infrastructure the British couldn't afford to every island, provide for the mutual defense of the colonies allowing the British to move its forces to more regions in need, and give the British oversight without micromanaging (Downes, 2013). 
The government of the Federation was divided up amongst representatives of the various islands. Though competing interests of the various leaders squabbled over who received more funding and economic aid, the Federation effectively unified the economies of their member provinces, the largest being Jamaica. The largest and most populous province in the West Indies, Jamaica also contributed the most to its economic stability. Whereas Jamaica experienced the most development, the lesser developed member states consistently borrowed into the Jamaican economy. While lesser provinces profited from the increased funding for infrastructure, Jamaica's reources seemed to slow to a halt (Downes, 2013).

The Federation Parliament was divided amongst the needs of the smaller islands and the demands of Jamaica. The Jamaicans represented the majority, and many within the islands felt Jamaica would soon be leading the Federation.

Issues at the Federal level continued to plague the Federation throughout 1959 and 1960. The Federation government faced issues trying to instill policy on the provincial governments. The island provinces, already fed up with British rule, were not willing to listen to another overarching encompassing government dictating policy to them (Mordecai, 1968). The provinces demanded a weak Federation government and provide simple public services and provide for the common defense. The provinces altered the Westminster system, creating the office of the Prime Minister to be a weak one (Cobley, 2000). The cabinet was small, and their budgets weak. Although Jamaica and Trinidad and Tobago together contributed $85 \%$ of the federal budget, their abilities were limited to handle major issues without taking loans or grants from the British government.

The British soon began to notice their plan was unfolding badly. Competing insular nationalism became more vocal than that of unified West Indian nationalism. Local popular support for the Federation soon began to dissipate. By 1961, support for the Federation and its government was at an all-time low. This was the result of support being lost amongst the member states, particularly Trinidad and Jamaica, the two largest countries of the Federation. Citizens within their island states became much more vocal about the independence of their home island than that of a unified West Indian state. The Federation Parliament began to recognize the Federation was beginning to fail, and that it wouldn't be long until the British lost their support for it (Mordecai, 1968).

However, during the height of the Federation's existence, infrastructures of, civil services, education, and public health experienced a major overhaul. It was argued that in a way it 
created the backbone for the civil services West Indian nations enjoy today. In 1960 alone, the University College of the West Indies grew from just a few hundred students to over 3,000 (UWI, 2014). Increased funding by the Jamaican and Trinidadian governments meant the University could now grow in students and in the courses and career opportunities offered. Because of this, in mid-1960 the UCWI opened up its second campus in St. Augustine, Trinidad in the location of the former Imperial College of Tropical Agriculture (ICTA) which had existed solely to teach locals how to harvest sugar and continue plantation economies. Following this, the UCWI opened up its next campus in Cave Hill, Barbados in 1963 and thirteen university centers headed by a Resident Tutor in the contributing territories of the Federation. Thus the first series of higher education campus opened across the West Indies for the first time (Cobley, 2000).

The largest accomplishment of the Federation was expanding the UCWI to become a major part of West Indian society and a known center of learning where international students could study in their respective fields. Education was proposed as one of the five major Federal services offered by the Federation Cabinet, the UCWI served as one of the top emphases aside from the Shipping Service, Supreme Court, Meteorological Service, and the West India Regiment defense force. Each of these was meant to exist through the contributions of the member states and help further unify the Federation as one cogent state (Mordecai 1968).

The UCWI however was given special emphasis, as education and accreditation became cornerstones to the Federation to create an enlightened and educated populace with equal opportunity for all West Indians. Securing an accredited university was a major accomplishment and pride of the West Indian leaders in the various countries. More so, these efforts signaled that the West Indies had put in place an efficient and dynamic system for international education for students throughout the world.

\section{Independence and Decolonialization: 1962-1970}

Beginning in 1954, the colonies of Great Britain began experiencing immense change as rising nationalist sentiments and calls for self-government pushed the British closer toward granting independence. Across the world, a mood of decolonialization swept the globe. As such, colonies began demanding their reward for being loyal subjects to the crown and supporting the war effort during WWII. But for some it wasn't enough. While many colonial legislatures wished to remain part of the Empire, rampant political activism and nationalist 
causes expanded on an international scale, which took the African continent by force. A majority of these nationalist causes and hyper-political activism were peaceful and nonviolent however, compared to situations in other European colonies such as in Angola and Mozambique where Portugal was locked in fighting a bloody war in the jungles of these countries against armed rebel independence groups. It was those peaceful transitions to power such as evidenced throughout the West Indies that brought about an end to British rule on the continent of Africa and in the West Indies while retaining the European tertiary education system which has survived to today.

This was the situation in Ghana in 1954, the first British colony in Africa to achieve independence following WWII. Beginning in the late 1940s, Africa became the subject to great decolonialization efforts and Pan-Africanist views. Nowhere was this truer than in Ghana. Ghana began pushing Britain to allow them to seek further independence and selfrule in their home government while national movements pushed for the British to pull out. Kwame Nkrumah, supported by the National People's Party began pushing the British to allow Ghana to create a more federal form of government, but the British felt that splitting power between multiple regions was not what the colony was ready for (Ronan, 1956). However by 1957, the Ghanaian colonial assembly achieved enough votes to pass a referendum of independence. The British, not wishing to fight anti-colonial movements any longer, acquiesced (Federal Research Division Library of Congress, 1995).

In 1957, Ghana's independence created a domino effect across the British Empire. One by one, Pan-African and nationalist parties in the West Indies began flooding colonial legislatures across the Empire. The British inadvertently fed these anti-colonial causes by educating many of the men who led them in Oxford and Cambridge including leading nationalists such as Jomo Kenyatta (Kenya), Kwame Nkrumah (Ghana), Julius Nyerere (Tanzania), Leopold Sedar Senghor (Senegal), and Felix Houphouet-Boigny (Cote d'Ivoire). Many of these nationalists returned home to incite protests and lead these movements in the streets and parliaments of these colonies. It took a decade following WWII to finally make the British, suffering financially trying to control all of these colonies, to bow to their demands for independence (Federal Research Division Library of Congress, 1995). What happened in Africa can easily be seen as a precursor to what would occur in the Caribbean.

With the numerous social and economic problems plaguing the Federation as well as its lack of political stability, the West Indies Federation collapsed in May 1962 when each member state voted to dissolve the Federation government. As such, the now autonomous West Indian 
states turned to Britain to request their individual independence. In places such as Jamaica and Trinidad, popular protests called for referendums to demand independence. With the Federation a thing of the past, the two largest states of the former federal government began polling for such a referendum (Federal Research Division Library of Congress, 1995).

The Jamaican independence movement, led by Alexander Bustamante, took control of the Jamaican Labour Party and began winning seats within the Jamaican legislature (Cobley, 2000). The People's National Party, led by former Federation Prime Minister Norman Manley lost the majority within Parliament in the 1962 election immediately following the referendum for the dissolution of the Federation. His immense unpopularity caused the JLP to ascend to power and elect their party leader, Alexander Bustamante, Prime Minister. This single referendum was called and a vast majority of voters polled that they wanted to achieve full independence from the British Empire. On August 6, 1962, Jamaica achieved its independence status from the British (Cobley, 2000).

At the same time, activists calling for political independence filled the streets of Port of Spain in Trinidad. In 1956, a Trinidadian politician named Eric Williams was chosen as party leader of the People's National Movement (PNM), a political nationalist party seeking Trinidad and Tobago's independence from the United Kingdom. Throughout the course of Trinidad's time within the Federation, the PNM won nearly every election by a landslide gaining more and more seats until they gained a majority in 1962 (Williams, 1964). The collapse of the Federation following Jamaica and Trinidad's referendum to leave, brought about the push for total independence from the British. As such, the PNM made it a party platform to transform Trinidad into an independent country from Great Britain. A national referendum was called and an overwhelming majority voted to become an independent nation. Trinidad gained its full independence on August 31, 1962 and Eric Williams, leader of the PNM, became Prime Minister. His party would dominate Trinidadian politics until 1981 under his premiership.

Throughout the dissolution of the Federation, the UWI continued to exist as a collective secondary institution for the West Indies. As independence movements continued to push the islands apart politically, the UWI continued to serve as a form of unifying institution for the Caribbean nations and colonies. 


\section{Growth and Expansion of the University System: 1962-1980}

The University of the West Indies continued to be the premier tertiary education institution in the Caribbean in the years following the Federation's collapse. It continued to expand as thousands of students enrolled following the independence of Jamaica and Trinidad as more educational opportunities became open to them as more funding, free from the constraints the Federation placed on them, flowed into the UWI's Mona and Trinidadian campuses. However, those countries lacking a UWI campus began investing in their own educational systems. Without having to pool their economies together anymore, the islands of the West Indies individually funded separate universities based off the UWI model.

By the early 1970s, there were universities springing up in several West Indian nations following independence. Education systems in general were vastly reformed as well, as free public primary and secondary education began in countries such as Barbados and St. Vincent. These improvements were increased with the merging of various Caribbean interests. In 1973, the Caribbean islands came together to form a supranational economic union known as CARICOM. Its goal was to help improve economic and social ills plaguing the newly independent islands.

The Caribbean Community, or CARICOM, was formed by the newly independent nations of Barbados, Jamaica, Guyana, and Trinidad and Tobago. CARICOM was formed from the Treaty of Chaguaramas which went into effect August 1, 1973. The goal of the treaty was to create an organization that helped cooperate the functioning of the numerous economies of the Caribbean to work together on foreign policy issues and economic integration as well as social and humanitarian issues (Gift \& Bell-Hutchinson, 2007). One of the biggest concerns of CARICOM became the goal of creating effective strategies for primary, secondary, and tertiary education in their member states (Gift \& Bell-Hutchinson 2007).

The organization had an impact on how the West Indian and Caribbean nations handled their education system. From this strategic collaboration, CARICOM managed to help newly independent nations get on their feet economically and socially by providing models and strategies to follow in laying the foundations of their tertiary education systems. The largest of the CARICOM member states, Barbados, Jamaica, Guyana, Trinidad, and St. Vincent and the Grenadines, formed the most up-to-date tertiary education systems through the assistance of the UWI and CARICOM. 
The University of the West Indies was critical as an international university in getting education on track in these countries. By the time CARICOM was founded the first alumni of the UWI were instrumental in helping create a faculty and staff foundation for the major secondary and tertiary institutions across the Caribbean (Cobley, 2000). Teachers and professors trained in the UWI and from abroad in the US, Canada, and Europe permeated as instructors in the university systems of these fledgling countries.

Prior to CARICOM's founding, most countries in the West Indies had barely enough funding for public primary education much less a secondary and tertiary education system. Through the efforts of CARICOM and UWI, these countries are now able to flexibly provide primary and secondary education to just about all of their young people. However, the challenge for maintaining sound fiscal and academic programs at the tertiary and higher educational levels will require governmental will in budgeting financial resources to enable each student to pursue affordable higher education offerings in the Caribbean.

Table 2 Education Systems of Various Caribbean States: An International Student Body

\begin{tabular}{|c|c|c|c|c|c|}
\hline Country & $\frac{\text { Primary }}{\text { Education }}$ & $\frac{\text { Secondary }}{\frac{\text { Education }}{\text { System }}}$ & $\frac{\text { Tertiary Education }}{\underline{\text { System }}}$ & $\underline{\text { Medical }} \underline{\underline{\text { Schools }}}$ & 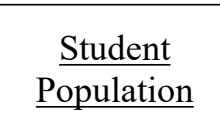 \\
\hline Barbados & $\begin{array}{l}\text { Free from } \\
\text { ages 4-11 } \\
\text { until students } \\
\text { sit for the } \\
\text { Common } \\
\text { Entrance } \\
\text { Exam }\end{array}$ & $\begin{array}{l}\text { Provided for } \\
\text { children } 11-18 . \\
\text { Must sit } \\
\text { through CXC } \\
\text { exams at } 16 \text { and } \\
\text { Al-Level CAPE } \\
\text { exams at } 18\end{array}$ & $\begin{array}{c}\text { Erdiston Teacher's } \\
\text { College, Samuel } \\
\text { Jackman Prescod } \\
\text { Polytechnic, } \\
\text { Barbados } \\
\text { Community College }\end{array}$ & $\begin{array}{c}\text { American } \\
\text { University of } \\
\text { Barbados } \\
\text { School of } \\
\text { Medicine } \\
\text { Nationality of } \\
\text { Foreign } \\
\text { Students in } \\
\text { AAIMS: } \\
\text { American: } 35 \% \\
\text { Canadian: } 25 \% \\
\text { European: } 40 \%\end{array}$ & $\begin{array}{c}\text { Black: } 92.4 \% \\
\text { White: } 2.7 \% \\
\text { Mixed: } 3.1 \% \\
\text { East Indian: } \\
1.3 \% \\
\text { Other: } 0.2 \% \\
\text { Nationality of } \\
\text { Foreign } \\
\text { Students in } \\
\text { AAIMS: } \\
\text { American: } \\
35 \% \\
\text { Canadian: } \\
25 \% \\
\text { European: } \\
40 \%\end{array}$ \\
\hline Guyana & $\begin{array}{l}\text { Free and } \\
\text { mandatory } \\
\text { from ages 5- } \\
\text { 16. Children } \\
\text { attend } 6 \text { year } \\
\text { primary } \\
\text { schools and } \\
\text { take exams } \\
\text { every } 2 .\end{array}$ & $\begin{array}{c}\text { Junior } \\
\text { secondary } \\
\text { school helps } \\
\text { students decide } \\
\text { if they want to } \\
\text { continue in } \\
\text { secondary } \\
\text { school or attend } \\
\text { vocational } \\
\text { schools }\end{array}$ & $\begin{array}{l}\text { There are } 10 \\
\text { technical/vocational } \\
\text { schools. The largest } \\
\text { are state-funded, } \\
\text { though private } \\
\text { institutions still exist }\end{array}$ & $\begin{array}{l}\text { Green Heart } \\
\text { Medical } \\
\text { University is } \\
\text { an independent } \\
\text { institution } \\
\text { offering } \\
\text { degrees in } \\
\text { health sciences } \\
\text { for the region }\end{array}$ & $\begin{array}{c}\text { East Indian: } \\
43.5 \% \\
\text { Black: } 30.2 \% \\
\text { Mixed: } \\
16.7 \% \\
\text { Amerindian: } \\
9.1 \% \\
\text { Other: .05\% }\end{array}$ \\
\hline Jamaica & $\begin{array}{l}6 \text { years of } \\
\text { primary } \\
\text { school }\end{array}$ & $\begin{array}{l}\text { Single-sex or } \\
\text { mixed co-ed } \\
\text { high schools. }\end{array}$ & $\begin{array}{l}\text { UWI - Mona } \\
\text { Campus (Colleges of } \\
\text { Law, Education, }\end{array}$ & $\begin{array}{l}\text { All American } \\
\text { Institute for } \\
\text { Medical }\end{array}$ & $\begin{array}{l}\text { Black: } 92.1 \% \\
\text { Mixed: } 6.1 \% \\
\text { East Indian: }\end{array}$ \\
\hline
\end{tabular}




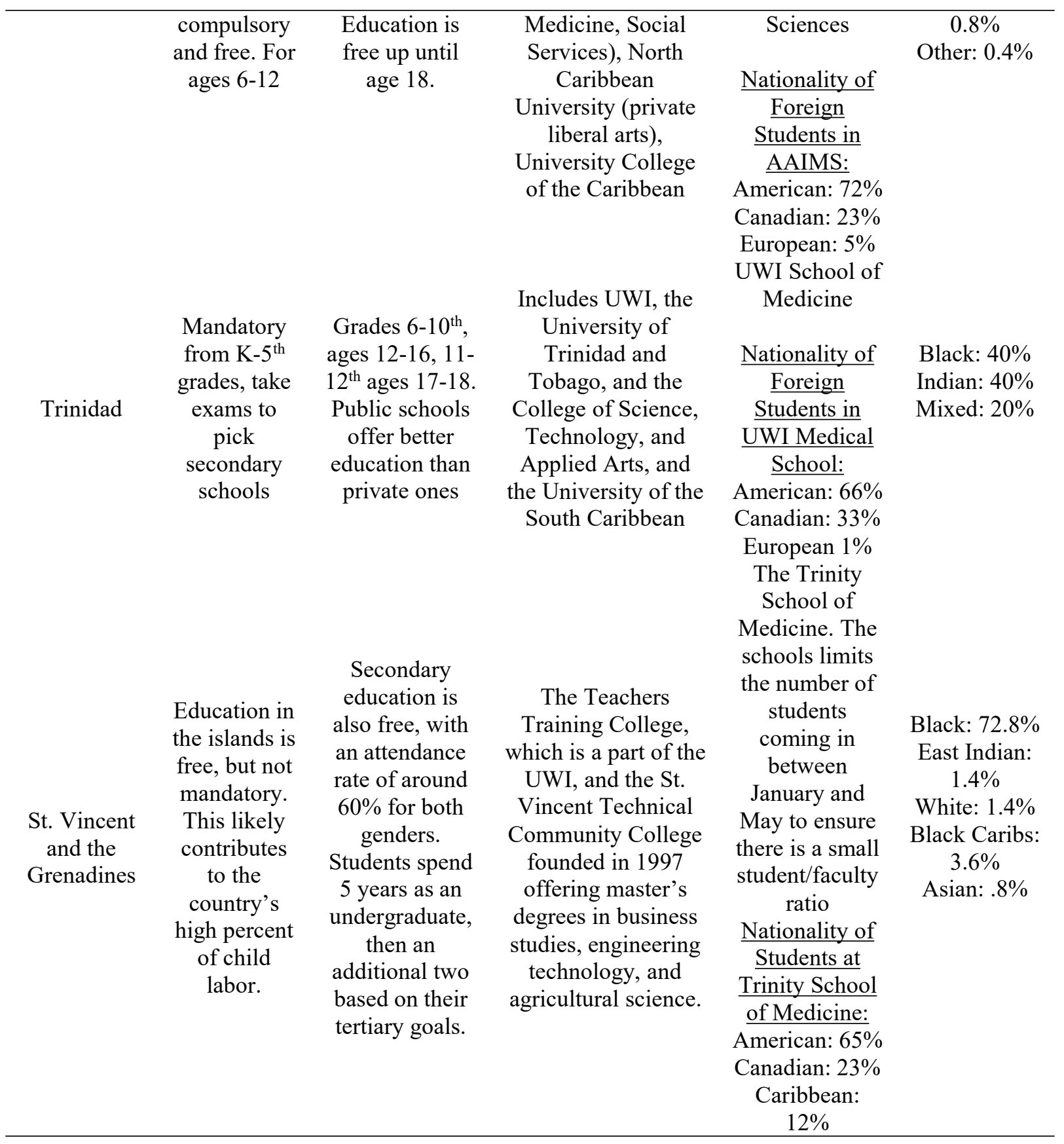

Table 2 shows that in most countries in the West Indies, free primary education from 4-11-12 is free and compulsory for all children. At the secondary level, free education up to 18 is available only in Barbados, Trinidad, Jamaica, and St. Vincent and the Grenadines. However, in countries like Guyana, and other West Indian states, the high school students must pay for their education. It should be noted that there is a proliferation of private secondary schools (Gift \& Bell-Hutchinson, 2007).

Table 2 also indicates that there are a mix of public and private college and universities. This Table 2 also shows the proliferation of medical and allied health schools that provide an international perspective and opportunities. These American schools include the American 
University of Barbados School of Medicine, Green Heart Medical University, the All American Institute for Medical Sciences, and Trinity School of Medicine. The chart below, Table 3, shows the diversity and international background of students.

Table 3 Percentage of Student Demographics

\begin{tabular}{|c|c|c|c|c|c|}
\hline Nation & Medical School & American & $\underline{\text { Canadian }}$ & European & Caribbean \\
\hline Barbados & $\begin{array}{l}\text { American University of } \\
\text { Barbados School of } \\
\text { Medicine }\end{array}$ & $35 \%$ & $25 \%$ & $40 \%$ & $0 \%$ \\
\hline Jamaica & $\begin{array}{l}\text { All American Institute for } \\
\text { Medical Sciences }\end{array}$ & $72 \%$ & $23 \%$ & $5 \%$ & $0 \%$ \\
\hline Trinidad & UWI School of Medicine & $62 \%$ & $33 \%$ & $1 \%$ & $4 \%$ \\
\hline St. Vincent & $\begin{array}{l}\text { Trinity University School } \\
\text { of Medicine }\end{array}$ & $65 \%$ & $23 \%$ & $0 \%$ & $12 \%$ \\
\hline
\end{tabular}

\section{Modern Influences in Caribbean Education: Internationalization of Education in the West Indies}

Because of the Caribbean's international status, their international universities have offered North American, European, and other students opportunities to study in the Caribbean. Because of this, these universities have rushed to achieve accreditation as well as bring in foreign students willing to pay due to their attractive affordable costs (Howe, 2000).

Originally, American and British students were enticed to enroll in St. George's University (SGU) Medical School throughout the late 1970s and early 1980s. The school hosted a broad foreign exchange program with the US, UK, and Canada. This served as one of the first West Indian universities that was truly an international school by foreign students. When the US invaded Grenada in 1983, it was their mission to evacuate American students trapped in the medical school. American troops successfully rescued them. Since then, the university has sought to rekindle its former standing as a premier medical school and option for American students and investors (Korn, 2014). Since 2013, however, St. George's has been working alongside a foreign private equity company to help expand their university. Altas Partners, a company specializing in salt mining operation in the region, recently struck a deal with the university (Roumeliotis, 2014). As a result, Canadian students now have an opportunity to enroll at the university, as SGU has recently opened a Canadian international program.

In addition to Grenada, St. Matthew's University in the Cayman Islands and Belize has cultivated the attention of interested American and British students seeking medical and 
veterinary licensure (Lambert, 2014). Because their licenses are considered ineligible in several US states, the American Veterinary Association and the Cayman Islands government joined together to create the Educational Commission for Foreign Veterinary Graduates (ECFVG) which was created to help ensure American students with degrees from St. Matthew's would be assured a medical license. This program ensures and affirms that these students are educated enough to receive licensure in all 50 states and allows those with a license to receive a certificate to practice in those states. It in a way creates a loophole around states that consider them ineligible (AVMA, 2014).

Two other universities in particular are international in scope: the All American Institute for Medical Sciences in Jamaica and the American University of Barbados. Both of these schools have been founded by American donors in cooperation between the US government and their respective local West Indian governments. Their goal is to offer premier educational opportunities in the medical field for both West Indian students as well as American students looking to study abroad. These universities have the accreditation that allows American, Canadian, and even European students to study at an affordable rate in the Caribbean and practice medicine at home. These universities allow these students to study there without the hassle of reciprocity and transferring foreign credits into their university systems when they return home.

Another such university offering such incentives is the Trinity School of Medicine in St. Vincent. Trinity is not an American or European funded school, but it does have the accreditation to compete with just about any medical school in the US or elsewhere. At the same time, it is also cost efficient. Trinity School of Medicine, with very high requirements, accepts a large number of foreign students. Surprisingly, American students make up $65 \%$ of that foreign makeup, followed by $23 \%$ Canadian, and $12 \%$ other foreign students (Reuters, 2014).

In a way, it can be said the Caribbean is recognized as a competitive international university system by Americans and Europeans, as well as Caribbeans from other regions. However this is in the form of students, and not colonists. Their attendance to West Indian institutions have indeed helped these universities attain critical accreditation requirements to be considered top academic performers in their field and rivaling European and American institutions of the same kind. 
St. Matthew's University in the Cayman Islands, for instance, has one of the finest medical degree programs in the West Indies; however the states of Indiana, Kansas, North Dakota, and especially California do not accept their degrees as eligible for licensure. In the United Kingdom, those who graduate from St. Matthew's University's Belize campus are ineligible for licensure, whereas the Cayman Islands campus is considered eligible for a license. Thus these institutions will have to continue to market their institutions programs and be competitive. The trend with other subject areas show that Caribbean educated students experience no challenges in transferring their degrees to other schools in Europe, North America, and elsewhere in the world.

\section{The Stability of Caribbean Education}

Throughout the last decade of the $20^{\text {th }}$ Century leading into today, education in the Caribbean continues to grow and expand. Higher level education is still relatively new, and is an experiment that continues to this day. Education, more than anything else, is considered one of the cornerstones of modern Caribbean society (Downes, 2013).

Educational initiatives, school planning, and strategies continue to be supported by the island governments of the West Indies to help their populations grow in tertiary knowledge. Through the efforts of CARICOM and the assistance of the United States, Canada, and the United Kingdom, education and higher education is now internationally recognized and will continue to be stable for the immediate future. With public budgets in most West Indian nations devoted to high-quality education, it leads to countries such as Jamaica, Guyana, Belize, Barbados, and Trinidad becoming competitive economic forces in the Caribbean and Central American marketplaces. Skilled workforces continue to bring revenue and prosperity to the Caribbean islands as tourism, trade, and local industry bring economic growth and transforms the region to fit in the global spotlight as a critical economic region. These improvements, both civil and economic, are due to a stable compulsory education given at an early age and encouraged throughout the lives of youth in the Caribbean countries.

Meanwhile, CARICOM continues to have a hand in developing Caribbean education. With the advent of CARICOM in 1973, the merging of strategies and curriculum has transformed West Indian education into a much larger regional, and international component. Students from across the Caribbean and the world attend major universities such as UWI, creating an atmosphere where the boundaries of nationality do not matter. In a way, education has helped 
unify the Caribbean. Education remains stable, and as a result, so too does the economies and society of the West Indies.

\section{Conclusion and Recommendations}

The sustenance of higher education in the West Indies will continue to be a national and regional priority of expenditures of GDP in every nation of the West Indies. The cost of students studying overseas and not returning to the Caribbean will continue to be a challenge. The more reciprocity of academic courses and degree completion among the West Indies, Europe, Canada, and the United States of America, the more validity and reliability will be accorded to the higher education institutions in the West Indies.

As this chapter winds down, it is essential to remember the words of Dr. Carter G. Woodson in 1926 who reminded us that by reflecting in the history of a group or thing, we are enlightened and develop a sense of pride and positive well-being. Dr. Woodson said in his book on the Miseducation of the Negro (1990) that,

When a group or individual fails to teach or learn about their history and culture, sooner or later their history and culture will be forgotten, and the group or individual will be rendered nameless and faceless. ( p. 21)

This discussion of tertiary higher education in the West Indies provides a useful face on the development and sustained contributions of the elementary, secondary, and the tertiary or higher education systems in the West Indies. The record shows that universities and colleges in the West Indies provided scholars at all levels in the West Indies and the world. The political leaders such as Norman Manley, Prime Minister of Jamaica and Eric Williams, Prime Minister of Trinidad got their education in the West Indies. The university system of UWI is internationally recognized with the highest levels of accreditation.

The highest scholarly achievements for West Indian Nobel Peace Prize winners were as follows: a) Sir Arthur Lewis, 1979 Nobel Laureate in Economics; joint winner with Theodore W. Schultz for their pioneering research in "Human Capital" development, b) Derek Walcott, born in St. Lucia; 1992 Nobel Laureate in Literature for a poetic piece of great luminosity in the area of poetry and literature, and c) Sir V.S. Naipaul, from Trinidad, 2001 Nobel Laureate in Literature for poetry and literature on history and culture. 
As the above discussion demonstrates, the West Indies higher education system has created a stable niche market in international education not only for students who are citizens of the various countries in the West Indies, but for students throughout the world. Because of the competitive academic offerings and high standards of these institutions, there are thousands of students from the United States, Europe, Canada, Latin America, Africa and Asia who will continue to seek admission to and matriculation in the many degree offerings at these higher education institutions in the West Indies.

There are some recommendations that arise from this study of the evolution and current status of higher education in the Caribbean that especially the West Indies, must address the following issues.

1. Each government must ensure that its GDP allocates funds to support elementary, secondary, and most of all, tertiary education of students who are desirous of pursuing their higher education goals at an institution of higher learning located in the Caribbean.

2. Since health care is still an important issue with diseases such as malaria, HIV-AIDS, and cholera as major causes of illness and death, it is necessary for Caribbean nations to grow its own physicians, nursing, and medical research staff from among Caribbean students. As stated the cost of medical education at Caribbean schools are substantially less than medical schools in Europe and North America. Thus, by increasing the number of Caribbeangrown physicians and medical personnel, the benefit will be an adequate supply of practitioners familiar with cultural dynamics and culturally competent to deliver medical care in the Caribbean nations.

3. A sobering note is that with the exception of the Trinity University School of Medicine in St. Vincent with 12\% Caribbean students and the University of the West Indies in Trinidad with 4\% Caribbean students, the remaining two medical schools - the All American Institute for Medical Sciences in Jamaica and American University of Barbados School of Medicine - both have $0 \%$ Caribbean students enrolled in these medical schools. Therefore, it is essential that each Caribbean government and nation pus for increased enrollment and admission of Caribbean students at each of these medical schools.

4. Finally, the movements in the Caribbean during the 1950s and 1960s that pushed for self-governance and self-determination. While the governments of the Caribbean have succeeded in self-governance and the creation of their own nations, the one critical issue is the waning financial support and enrollment of Caribbean students in the tertiary education institutions. Caribbean governments must advocate for increase enrollment coupled with 
attractive incentives, including financial scholarships and resources to entice Caribbean students to study at home rather than aboard in Europe or North America, including Mexico, the United States of America, and Canada.

\section{References}

[1] Ajayi, J. F., Goma, L. H., \& Johnson, G. A. (1996). The African experience with higher education. Athens, Ohio: Ohio University Press.

[2] American Veterinary Medical Association. (n.d.). ECFVG - Certification Main. Retrieved from https://ecfvg.avma.org/ECFVG/ AVMACertification Main.aspx

[3] Banks, J. (2009). Teaching strategies for ethnic studies ( $5^{\text {th }}$ ed.). Needham Heights, MA: Allyn and Bacon.

[4] Braithwaite, L. (1965). The role of the university in the developing society of the West Indies. Social and Economic Studies, 14(1), 76-87. Retrieved from http://www.jstor.org/stable/27853833

[5] The British Caribbean Federation Act (1956). Retrieved from http://www.legislation.gov. uk/ukpga/Eliz2/10-11/19

[6] Cobley, A. G. (2000). Historical Development in the Anglophone Caribbean. In G. D. Howe (ed.), Higher education in the Caribbean: Past, present, and future directions (pp. ??-??). Kingston, Jamaica: The University of the West Indies Press.

[7] Downes, A. (2013). Financing Tertiary Education [PowerPoint Slides]. Retrieved from http://www.caribank.org/uploads/2013/05/The-Case-Study-of-UWI.pdf

[8] Caban, P., Cruz, B., Carrasco, J., \& Garcia, J. (1994). The Latino experience in U.S. history. Paramide, NJ: Globe Fearon.

[9] Federal Research Division Library of Congress. (1995). Ghana: A Country Study. Retrieved from http://memory.loc.gov/master/frd/frdcstdy/gh/ghanacountrystud00berr_0/ghanacountryst ud00berr_0.pdf

[10] Gordan, S. C. (1962). The Keenan report, 1869 part I: The elementary school system in Trinidad. Caribbean Quarterly, 8(4), 3-16. Retrieved from http://www.jstor.org/stable/40652829 
[11] Gift, S. I. \& Bell-Hutchinson, C. (2007). Quality assurance and the imperatives for improved student experiences of higher education: The case of the University of the West Indies. Quality in Higher Education, 13, 145-157

[12] Howe, G. (2000). Higher education in crisis. University of the West Indies Press.

[13] Korn, M. (2014, August 8). St. George's University lands \$750M investment deal. Wall Street Journal. Retrieved from http://blogs.wsj.com/atwork/2014/08/08/ st-georgesuniversity-lands-750m-investment-deal/

[14] Lambert, M. (2014, August 8). Atlas partners with St. George's University. Retrieved from http://www.altaspartners.com/altas-partners-with-st-georges-university/

[15] Mordecai, J. (1968). Federation of the West Indies. Evanston, IL: Northwestern University Press

[16] Morrison, E. (2014). Higher Education in the Caribbean Region. University of the West Indies Press, February 21. Issue No. 308.

[17] Roberts, J., Rodriguez, A. M., \& Herbst, J. (1996) Exporting models. In Ridder-Symoens, H. Reugg, W. (eds.) A history of the university in Europe. Vol. II: Universities in early modern Europe (1500-1800) (pp.256-282). Cambridge University Press.

[18] Ronan, T. P. (1956, September 19). British set March 6 as date of freedom for the Gold Coast; Gold Coast gets date of freedom pledge is welcomed. The New York Times.

Retrieved May from http://www.nytimes.com/1956/09/19/archives/british-set-march-6as-date-of-freedom-for-the-gold-coast-gold.html

[19] Roumeliotis, G. (2013, March 18). Historic St. George's University explores sale. Reuters. Retrieved from http://www.reuters.com/article/2013/03/18/ stgeorgesuniversity-sale-idUSL6N0CAFEF20130318

[20] The University of the West Indies (UWI). (2014). About the UWI: An institution with a rich history. Retrieved from http://www.uwi.edu/history.asp

[21] Williams, E. (1964). British historians and the West Indies. Port of Spain: P.N.M. Publishing Company

[22] Woodson, C. G. (1990). The miseducation of the negro. Washington, DC: Africa World Press 